\title{
Resilience of Hydrobia ulvae populations to anthropogenic and natural disturbances
}

\author{
P. G. Cardoso ${ }^{1, *}$, A. Brandão ${ }^{1}$, M. A. Pardal ${ }^{1}$, D. Raffaelli ${ }^{2}$, J. C. Marques ${ }^{1}$ \\ ${ }^{1}$ IMAR - Institute of Marine Research, Department of Zoology, University of Coimbra, 3004-517 Coimbra, Portugal \\ ${ }^{2}$ Environment Department, University of York, Heslington, York YO10 5DD, UK
}

\begin{abstract}
In the Mondego estuary (Portugal), several mitigation measures (nutrient loading reduction, seagrass bed protection and freshwater circulation enhancement) were implemented in 1998 to promote the recovery of the seagrass bed and the entire surrounding environment following a long period of eutrophication. In the present study we evaluate the success of this restoration project, by comparing the water nutrient concentrations, the seagrass-cover extent and the dynamics of Hydrobia ulvae, before and after implementation of the management measures. During the period in which environmental quality declined, H. ulvae abundance, biomass and growth production declined, associated with the almost total disappearance of the macrophyte Zostera noltii. However, after the implementation of management measures, dissolved nutrients and green macroalgal blooms were much reduced, and the seagrass bed started to recover. The $H$. ulvae population also responded positively, becoming more structured (including individuals of all age classes), with higher abundance and biomass. Major flood events demonstrated that the resilience of the $H$. ulvae population may have been lowered by the original chronic stressor (eutrophication). The population structure of $H$. ulvae in the most stressed site continued to be dominated by small individuals despite the improvements in water quality, probably a result of the absence of seagrass plants at this site. Estuarine restoration programmes need to recognise the importance of understanding the resilience of populations and the interactions of multiple stressors.
\end{abstract}

KEY WORDS: Eutrophication $\cdot$ Ecological restoration $\cdot$ Management $\cdot$ Zostera noltii bed $\cdot$ Hydrobia ulvae

\section{INTRODUCTION}

Eutrophication, or nutrient enrichment, of coastal waters is now widely recognised as a major worldwide problem (Diaz \& Rosenberg 1995, Norkko \& Bonsdorff 1996a,b, Raffaelli et al. 1998). One manifestation of estuarine eutrophication is a replacement of seagrasses and slow-growing macroalgae by opportunistic macroalgae and phytoplankton (reviewed in Schramm \& Nienhuis 1996, Valiela 1997). Loss of the seagrass bed leads to changes in the associated biological communities (Reise et al. 1989, Flindt et al. 1997, Dolbeth et al. 2003, Cardoso et al. 2004) and the functions, services and goods that a seagrass bed provides (Clark 1996, de Jonge et al. 2000, Duarte 2000, 2002, Jackson et al. 2001).
In recent years there has been an enormous upsurge in interest in restoration as a technique for reversing habitat degradation worldwide (Hobbs \& Norton 1996, de Jonge et al. 2000). Restoration ecology has been hailed as a new paradigm for biological conservation (Peterson \& Lipcius 2003). The purpose of restoration projects is to return a habitat from an altered or disturbed condition to a previously existing natural condition (Kennish 2000). The success of restoration plans depends on several key processes: (1) identifying and understanding the processes which have driven the observed ecological changes; (2) determining realistic objectives and measures of success; (3) developing methods for implementing the goals and incorporating them into management; and (4) monitoring the restora- 
tion and assessing its success (Hobbs \& Norton 1996, Kennish 2000, Pardal et al. 2004). There is compelling evidence that the resilience of a seagrass bed is typically low (Hobbs \& Norton 1996, Kendrick et al. 2002, Cardoso et al. 2004), due to the major shifts in sediment properties that occur when seagrass plants are lost, which make the sediment unsuitable for seagrass recruits. Restoration initiatives that are based exclusively on reducing nutrient inputs from further upstream are thus unlikely to be sufficient on their own to restore seagrass beds (Cardoso et al. 2004).

In addition to the seagrass plants themselves, a seagrass bed supports a rich invertebrate fauna, and the resilience of these populations is not well understood. In the present study we evaluate the success of a restoration project implemented in a well-documented seagrass habitat experiencing eutrophication in the Mondego estuary (Marques et al. 1997, 2003, Lillebø et al. 1999, Pardal et al. 2000, 2004, Cardoso et al. 2002, 2004, Dolbeth et al. 2003). We focus on the dynamics of the mud snail Hydrobia ulvae, one of the most abundant species in the seagrass Zostera noltii meadows (Lillebø et al. 1999, Cardoso et al. 2002, Dolbeth et al. 2003), before and after the establishment of management measures. Such long-term data sets (10 yr) are required in order to capture slow ecological processes (e.g. population dynamics of long-lived organisms), rare events (e.g. floods) and complex phe-nomena, for which a long time is required to detect changes or trends (Franklin 1989).

\section{MATERIALS AND METHODS}

Study site. The Mondego estuary, located on the Atlantic coast of Portugal $\left(40^{\circ} 08^{\prime} \mathrm{N}, 8^{\circ} 50^{\prime} \mathrm{W}\right)$ comprises 2 different arms, north and south, separated by an alluvium-formed island (Fig. 1). The north arm is deeper (4 to $8 \mathrm{~m}$ during high tide, tidal range about 1 to $3 \mathrm{~m}$ ) and constitutes the principal navigation channel and the location of the Figueira da Foz harbour. The south arm is shallower (2 to $4 \mathrm{~m}$ during high tide, tidal range 1 to $3 \mathrm{~m}$ ) and is almost silted up in the upper zones, constituting a kind of coastal lagoon in which the water circulation is mostly dependent on the tides and on the freshwater input from the Pranto River (Marques et al. 1993, 1997, Flindt et al. 1997, Lillebø et al. 1999, Pardal et al. 2000). Discharge from the
Pranto River is controlled by a sluice (Flindt et al. 1997, Lopes et al. 2000, Pardal et al. 2000) and is regulated according to the irrigation needs of the Mondego Valley rice fields (Martins et al. 2001).

Since the 1980s, eutrophication of the estuary has taken place as a result of excessive nutrient release into coastal waters, and the seagrass Zostera noltii bed has been drastically reduced in areal extent and biomass in the south arm (Cardoso et al. 2004, Pardal et al. 2004). For instance, a seagrass bed that in the mid-1980s measured 15 ha by areal extent was progressively reduced to 1.6 ha by 1993 and to less than $300 \mathrm{~m}^{2}$ by 1997 (Fig. 1). In 1998, several mitigation measures were applied. The hydraulic regime in the south arm was improved by enlarging the connection between the 2 arms. The Pranto sluice-opening regime was minimised in such a way that most of the freshwater from the Pranto River (loaded with nutrients) is discharged directly into the north arm (by another sluice located further upstream), reducing the nutrient loading in the south arm. In addition, the remaining seagrass patches were protected with wooden stakes to prevent further disturbance of that area (by fishermen digging in the

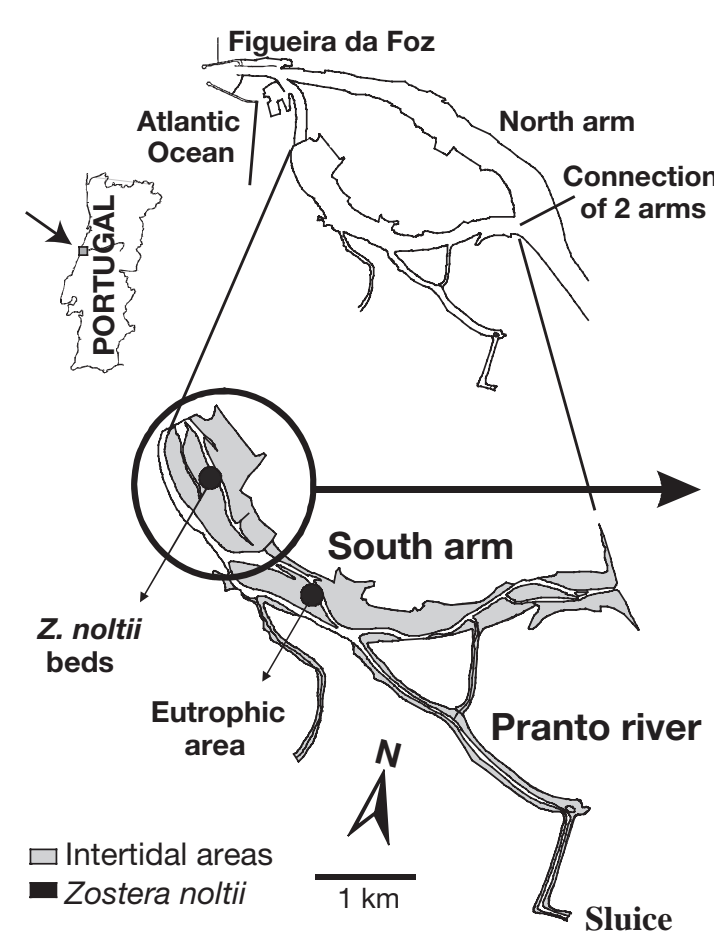

Fig. 1. Location of the sampling stations and change in the area covered by Zostera noltii in the south arm of the Mondego estuary. Mapping of benthic vegetation is based on field observations, aerial photographs and GIS methodology (ArcView GIS version 8.2)

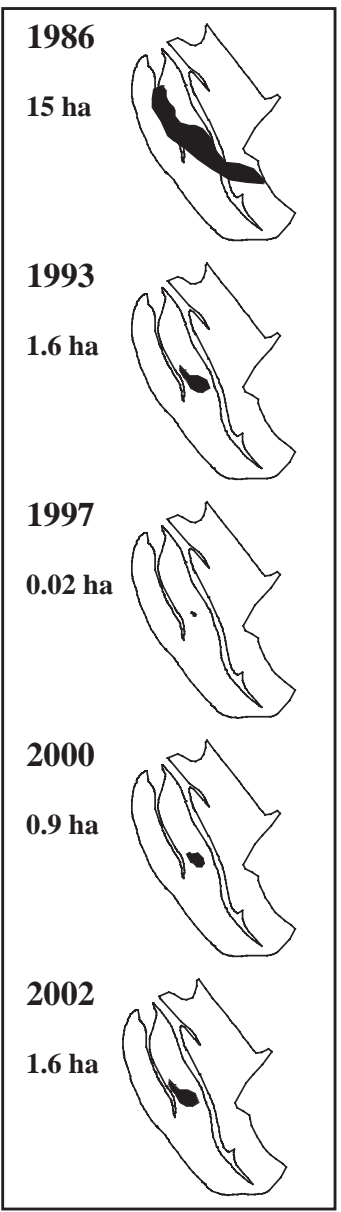


sediment for bait), and several forums were convened to apprise local people of the ecological and economic importance of the seagrass bed.

Two study areas were established in the southern arm of the estuary: (1) the seagrass bed located downstream and (2) the eutrophic area further upstream. Originally, in the early eighties, this upstream area was also covered by rooted macrophytes; however, as the eutrophication increased, Zostera noltii declined progressively (Fig. 1). At the time of this study, this area was characterised by the absence of seagrasses (for more than $15 \mathrm{yr}$ ) and was covered seasonally by spring green macroalgae, especially Enteromorpha sp. (actually Ulva sp., according to the recent revision of Hayden et al. 2003). For a detailed description of these areas see Pardal et al. (2000), Cardoso et al. (2002, 2004) or Marques et al. (2003).

Field survey programme. In the eutrophic area, the Hydrobia ulvae population was monitored from January 1993 to January 1997 and again from January 1999 to December 2001. In the seagrass bed, the population was monitored from January 1993 to September 1995 and again from January 1999 to December 2002. From 1997 to 1998 the areas were not sampled to aid recovery of the seagrass bed.

Samples were collected fortnightly for the first 18 mo of study and monthly for the rest of the study period. On each occasion 6 to 10 sediment cores $\left(141 \mathrm{~cm}^{2}\right.$ surface area) were taken to a depth of $15 \mathrm{~cm}$ and washed in estuarine water through a $500 \mathrm{~mm}$ mesh sieve. The remainder (sediment, rooted macrophytes, algae and fauna) was preserved in $4 \%$ buffered formalin.

On each occasion, during the morning, temperature and salinity were measured in situ during low tide. Water samples were collected for analysis of dissolved inorganic nitrogen (DIN) and dissolved inorganic phosphorus (DIP). Data on monthly precipitation derive from the nearby city of Coimbra (Instituto de Meteorologia, Coimbra forecast station).

Seagrass and macroalgal analysis. In the laboratory, plant material was sorted and separated into Chlorophycea, Rhodophycea and Zostera noltii (leaves and rhizomes). After that, the material was dried (for $48 \mathrm{~h}$ at $60^{\circ} \mathrm{C}$ ) and the ash-free dry weight (AFDW) was assessed after combustion of samples for $8 \mathrm{~h}$ at $450^{\circ} \mathrm{C}$.

Hydrobia ulvae. $H$. ulvae were counted and 2 shell measurements were obtained: total shell length (TSL) and maximum width (MW). The last one was most suitable, since a great number of snails had damaged shells. In the present paper we used the conversion equation (MW $=0.4369 \mathrm{TSL}+$ 0.2091, $\mathrm{n}=339, \mathrm{r}=0.97$; Lillebø et al. 1999). Length-weight relationships were determined for production estimates. Preliminary ANOVA of length $\times$ AFDW relationships indicated no significant seasonal differences, and an overall regression equation was used (AFDW $=0.0564 \mathrm{TSL}^{2.2381}, \mathrm{n}=191, \mathrm{r}=0.98$; Lillebø et al. 1999). Biomass was calculated as AFDW (loss after $8 \mathrm{~h}$ of incineration at $450^{\circ} \mathrm{C}$ of specimens previously dried at $60^{\circ} \mathrm{C}$ for $72 \mathrm{~h}$ ). The same procedure was used to quantify organic matter content of the sediment.

Growth rates were estimated by tracking recognisable cohorts in size-frequency distributions over successive sample dates using the ANAMOD software package (Nogueira 1992).
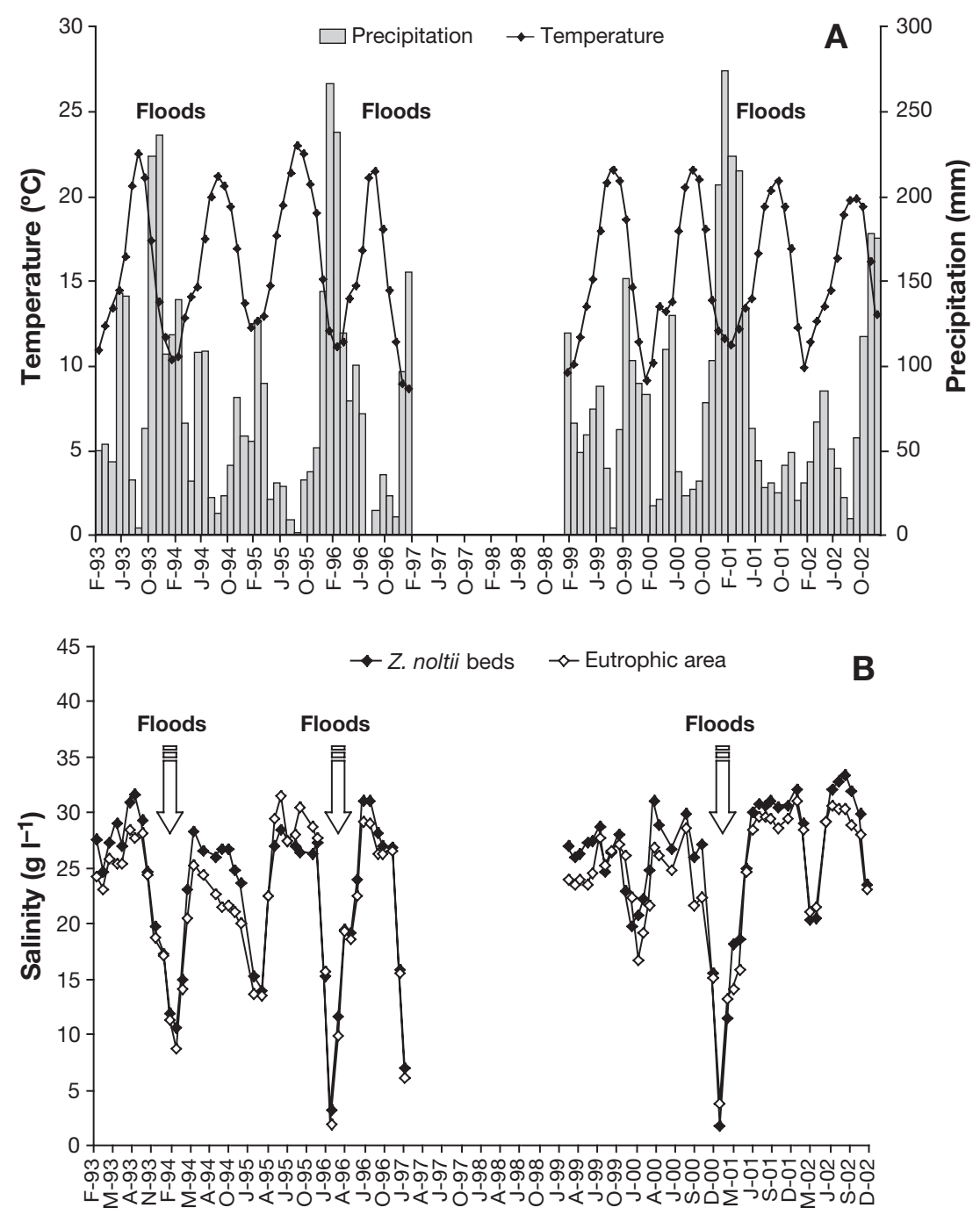

Fig. 2. Long-term variation in (A) temperature and rainfall and (B) salinity 

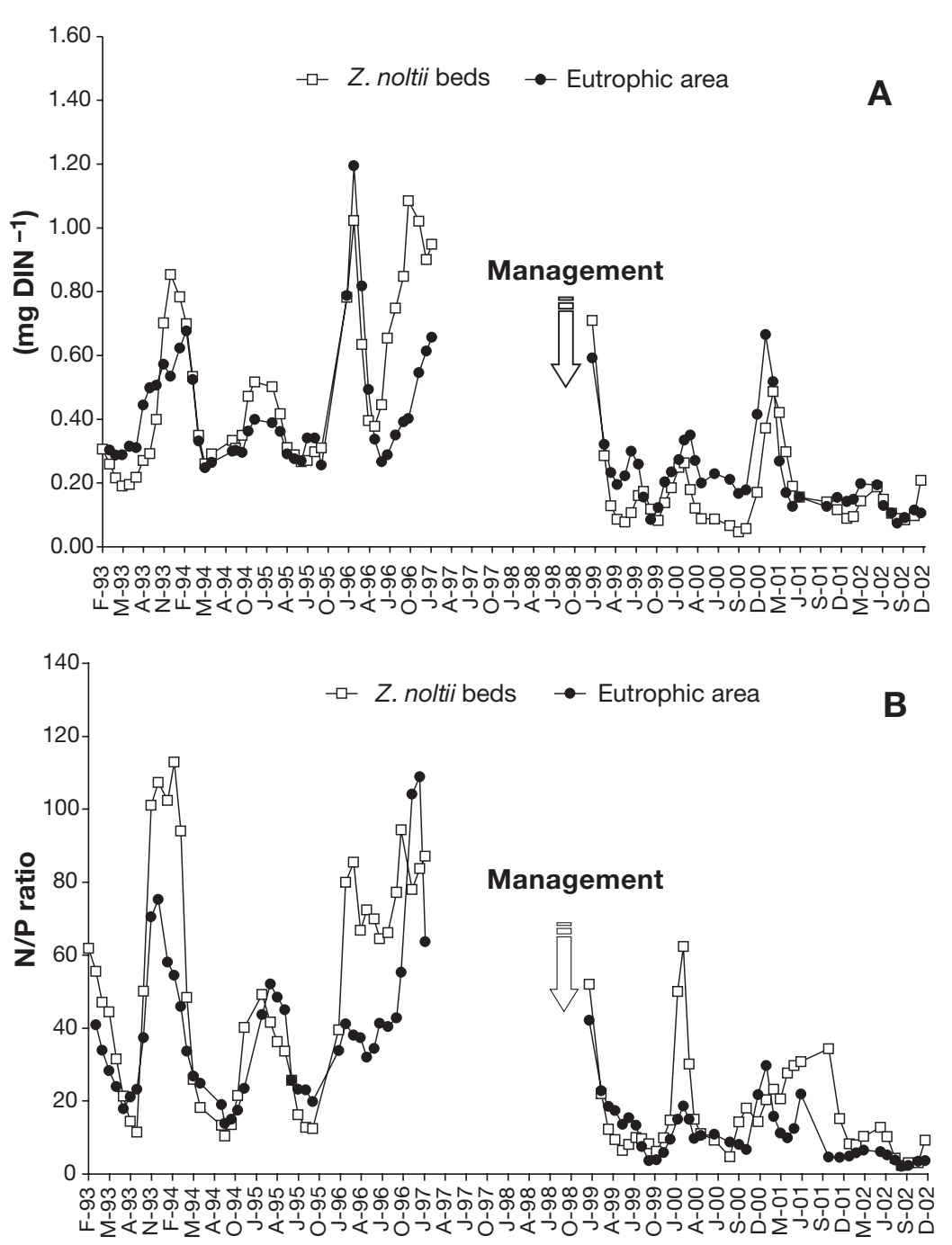

Fig. 3. Long-term variation in (A) DIN concentrations and (B) N/P ratio

\section{RESULTS}

\section{Precipitation and salinity}

The Mondego estuary is a warm temperate coastal system in a region with a basically Mediterranean temperate climate. In addition to the clear annual pattern of rainfall over the $10 \mathrm{yr}$ period, 3 winters of above-average precipitation (1993/94, 1996/97 and 2000/01) are apparent (Fig. 2A). During periods of intense rainfall, salinity declined dramatically, occasionally reaching $<5 \mathrm{~g} \mathrm{l}^{-1}$ (Fig. 2B).

\section{Nutrient concentrations}

DIN concentrations were significantly different before and after the introduction of mitigation measures for both sites (Kruskal-Wallis test, $H=83.14$, p < 0.05), being markedly reduced in the post-mitigation period for both areas (Fig. 3A). The same pattern was also observed for N/P ratios (Fig. 3B). Significant differences were detected between pre- and post-mitigation periods for both sites (Kruskal-Wallis test, $H=$ 79.76, p < 0.05). Nevertheless, no statistical differences were observed between the 2 sites for either DIN (Kruskal-Wallis test, $H=83.14, \mathrm{p}>0.05)$ or the N/P ratio (Kruskal-Wallis test, $H=79.76$, $\mathrm{p}>0.05)$.

\section{Seagrass and macroalgal biomass} (1986).

Total values of $P$ for the population are expressed as

$$
P=\sum_{n=1}^{N} P_{\mathrm{cn}}
$$

where $P_{\mathrm{cn}}$ is the growth production (biomass assimilated by a constant number of individuals in a certain period of time) of cohort n. $\bar{B}$ (annual mean population biomass) is expressed as

$$
\bar{B}=(1 / T) \sum_{n=1}^{N}\left(\bar{B}_{\mathrm{n}} t\right)
$$

where $T$ is the period of study (annual cycles); $N$ is the number of successive cohorts in the period $T$ (year); $\bar{B}_{\mathrm{n}}$ is the mean biomass of cohort $n_{\text {; }}$ and $t$ is the duration of the cohort $\mathrm{n}$ (in our case, 16 to $20 \mathrm{mo}$, according to Cardoso et al. 2002).
Regarding total seagrass biomass and comparing the slope of the pre-mitigation period with the one of the post-mitigation period, significant differences were observed between them (Student's $t$-test, $t_{107}=6.12, \mathrm{p}<$ 0.05). From 1993 to 1997, the total biomass of Zostera noltii declined sharply, and in early 1998 the lowest biomass ( $5 \mathrm{~g} \mathrm{AFDW} \mathrm{m}^{-2}$ ) was recorded. After the introduction of mitigation measures in 1998, there was a gradual recovery of the seagrass bed (Figs. 1 \& 4A). In contrast, in the eutrophic area, there were significant differences in green macroalgal biomass between the pre- and post-mitigation periods (Wilcoxon 2-sample test, $W=2015.5, \mathrm{p}<0.05)$. In 1993 and 1995 algal blooms were common, but they were never present after post-mitigation measures (Fig. 4B). 

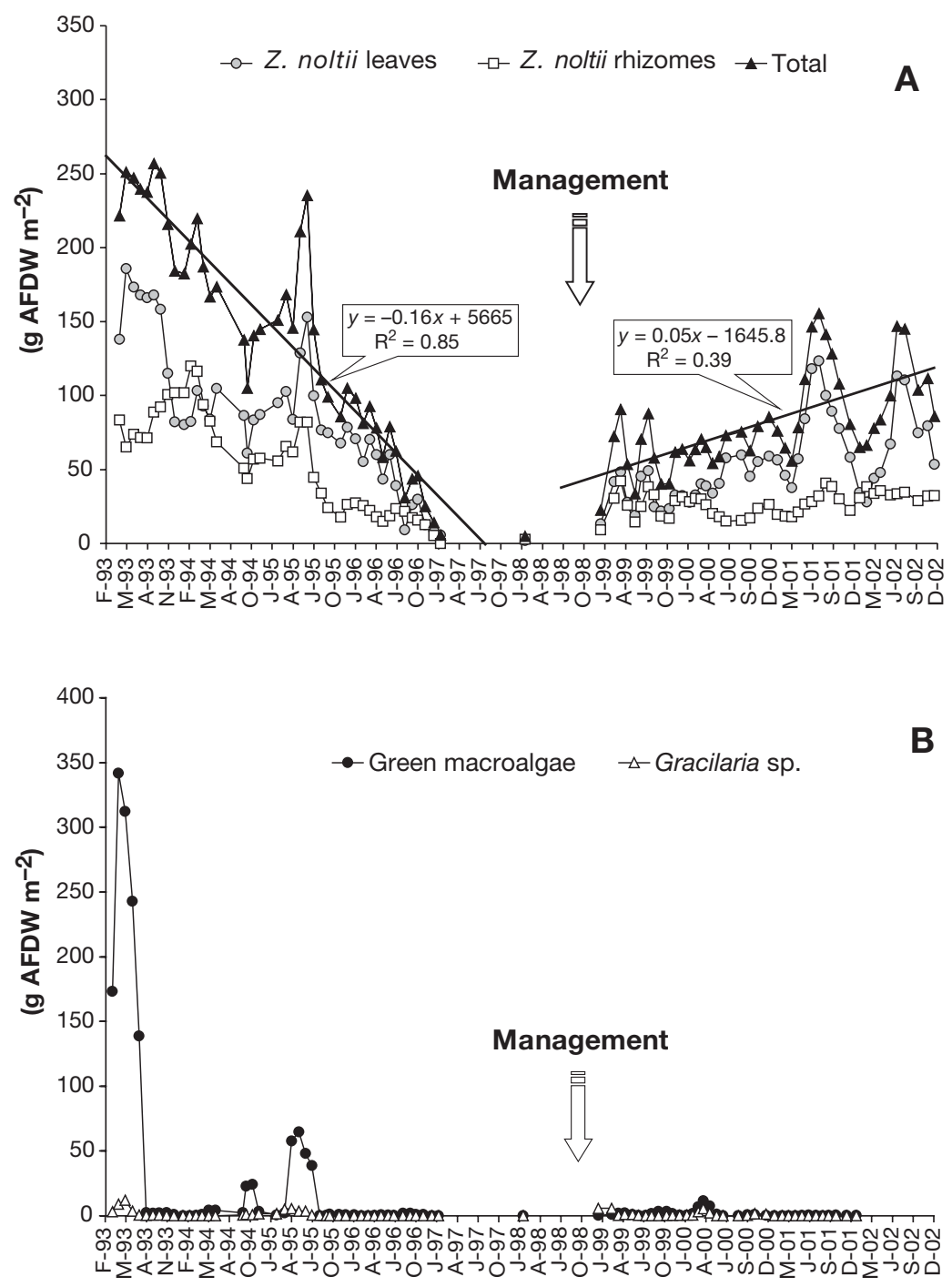

Fig. 4. Long-term variation of plant biomass. (A) Seagrass in the Zostera noltii bedi $_{i}(B)$ macroalgae in the eutrophic area

\section{Population density}

Hydrobia ulvae abundance and biomass changed markedly during the study period. In the seagrass bed from 1993 to 1995, H. ulvae biomass was relatively constant (range 50 to $100 \mathrm{~g} \mathrm{~m}^{-2}$ ). Nevertheless, following the decline of Zostera noltii, biomass of $H$. ulvae was reduced by approximately an order of magnitude (Fig. 5A). In the $Z$. noltii bed, significant differences in $H$. ulvae biomass were observed between the pre- and post-mitigation periods $\left(t_{93}=5.54, \mathrm{p}<0.05\right)$. H. ulvae appeared to start to recover until the autumn of 2000, when a period of prolonged and heavy rainfall (Fig. 2A) was associated with a decline in both density and biomass. However, the population seemed to begin recovery again in 2002 (Fig. 5A).
In the eutrophic area, the pattern of change was completely different. Density and biomass of Hydrobia ulvae declined significantly throughout the study period, with no obvious indication of recovery (Fig. 5B). Significant differences were observed in $H$. ulvae biomass between the pre- and post-mitigation periods $\left(t_{95}=\right.$ $2.53, \mathrm{p}<0.05)$. It should be noted that the recovery of the seagrass bed $H$. ulvae population after flood events in 2001 appears slower than that in 1994. Regarding $H$. ulvae biomass, and comparing the slope in 1994 (from March 1994 to December 1994) with the one in 2001 (from March 2001 to December 2001), significant differences were observed between them ( $H$. ulvae biomass, $t_{14}=6.28, \mathrm{p}<$ 0.05). Despite the huge increase in $H$. ulvae biomass in 2002, the population took a longer time (almost 1 yr) to achieve the same previous values, after the second flood event (2001), comparatively to the first flood event (1994), in which the recovery was much more rapid.

\section{Population structure and growth}

Marked differences in the population structure were observed at the 2 sites (Fig. 6). In the seagrass bed from 1993 to 1995, several modes are apparent in the population representing individuals of all age classes (juveniles $<1 \mathrm{~mm}$; young individuals 1 to $1.5 \mathrm{~mm}$; adults $>1.5 \mathrm{~mm}$ ) (Anderson 1971, Planas \& Mora 1987, Cardoso et al. 2002). In 1999, the population at this site was dominated by small individuals, being significantly different from that in 1994 ( $\chi^{2}$ test, $p<0.05$ ), and only by the spring of 2001 did larger snails reappear in the size-frequency distributions. Significant differences were also observed between the population in 1999 and 2001 ( $\chi^{2}$ test, $\mathrm{p}<$ 0.05). In contrast, the eutrophic area was dominated by small individuals of Hydrobia ulvae, over the entire study period, with few adults present (Fig. 6).

\section{Production}

Growth production $(P)$ and mean population biomass $(\bar{B})$ of Hydrobia ulvae were significantly higher in the Zostera noltii bed than at the eutrophic site (growth production: $t_{8}=3.34, \mathrm{p}<0.05$; mean population bio- 


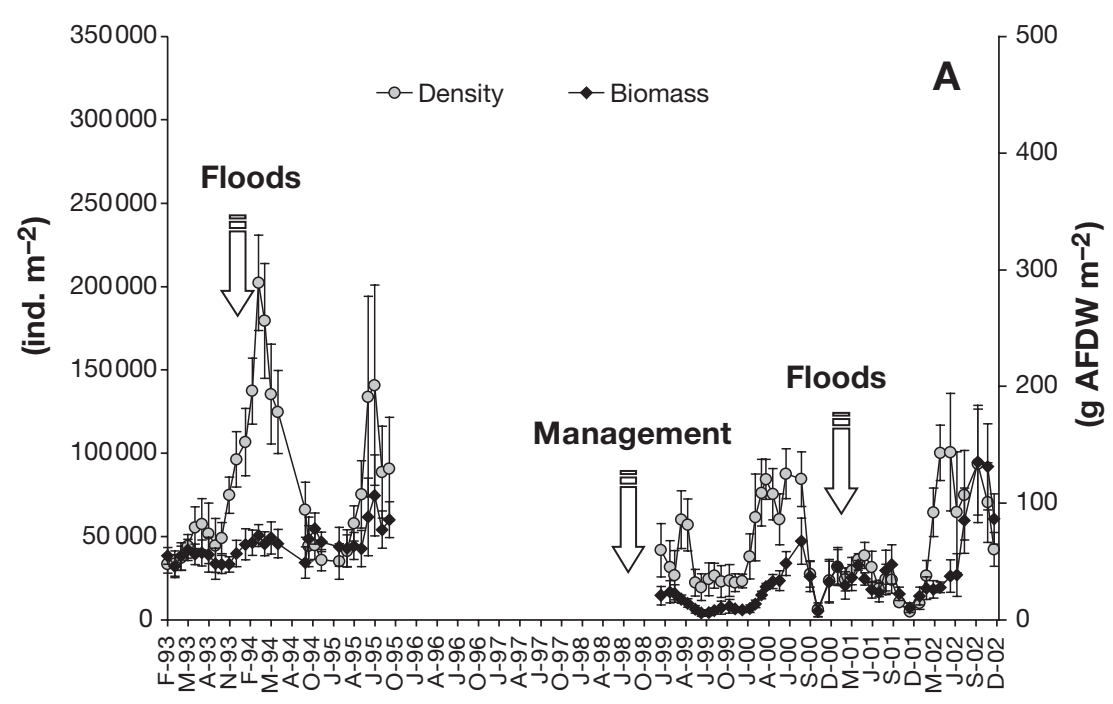

mass: $\left.t_{8}=3.28, \mathrm{p}<0.05\right)($ Table 1$)$. The highest values were recorded in 1994 in the seagrass bed. After the introduction of mitigation measures, the values of growth production and mean biomass in the seagrass site tended to increase. In 2001, the populations at both sites were clearly impacted by floods, but by 2002, the production values in the seagrass bed were similar to those observed in the beginning of the study (Table 1). In the eutrophic area, there was a general, gradual decline in $P$ values. On the other hand, the $P / \bar{B}$ ratios were always higher in the eutrophic area.

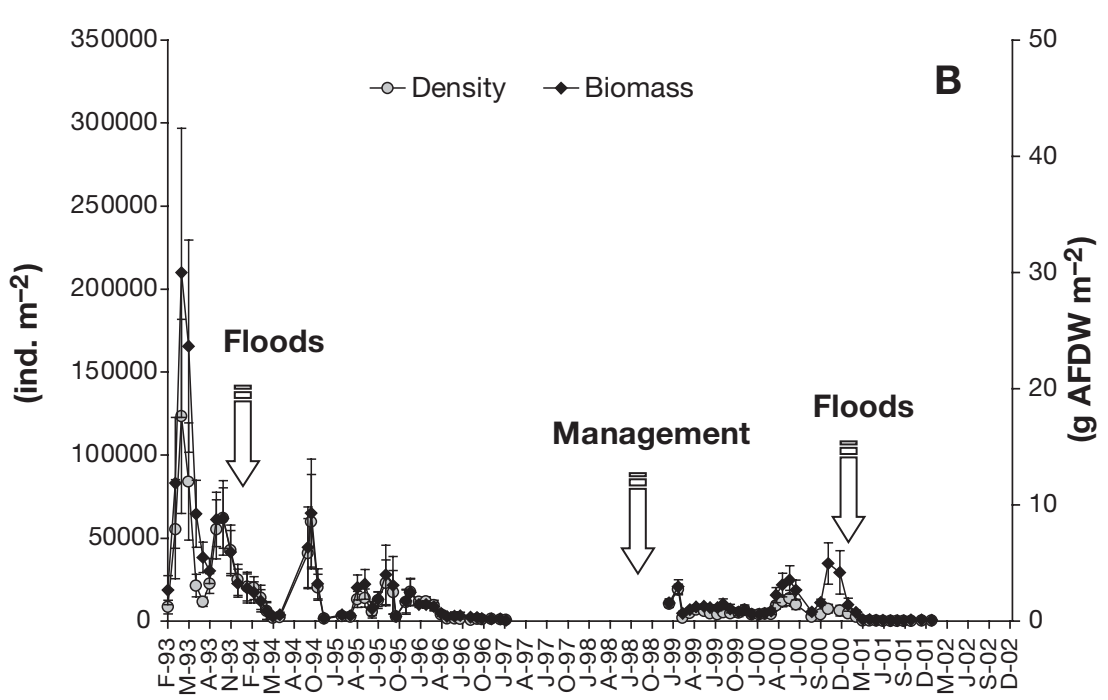

Fig. 5. Variation of Hydrobia ulvae density and biomass in the 2 study areas.

(A) Zostera noltii bed; (B) eutrophic area

Table 1. Growth production estimations of Hydrobia ulvae for both areas. -: n data available

\begin{tabular}{|c|c|c|c|c|c|c|}
\hline & \multicolumn{3}{|c|}{ — Zostera noltii bed — } & \multicolumn{3}{|c|}{ — Eutrophic area — } \\
\hline & $\begin{array}{c}P \\
(\mathrm{~g} A F D W \\
\mathrm{m}^{-2} \mathrm{yr}^{-1} \text { ) }\end{array}$ & $\begin{array}{c}\bar{B} \\
(\mathrm{~g} \mathrm{AFDW} \\
\mathrm{m}^{-2} \text { ) }\end{array}$ & $P / \bar{B}$ & $\begin{array}{c}P \\
(\mathrm{~g} \mathrm{AFDV} \\
\left.\mathrm{m}^{-2} \mathrm{yr}^{-1}\right)\end{array}$ & $\begin{array}{c}\bar{B} \\
\text { AFDW } \\
\mathrm{m}^{-2} \text { ) }\end{array}$ & $P / \bar{B}$ \\
\hline 1993 & 125.08 & 59.24 & 2.11 & 45.73 & 9.37 & 4.87 \\
\hline 1994 & 202.53 & 74.14 & 2.73 & 10.86 & 2.38 & 4.56 \\
\hline 1995 & - & - & - & 8.88 & 3.30 & 2.68 \\
\hline 1996 & - & - & - & 2.80 & 0.95 & 2.94 \\
\hline 1999 & 26.77 & 11.11 & 2.40 & 3.21 & 1.09 & 2.94 \\
\hline 2000 & 95.40 & 29.33 & 3.25 & 8.19 & 2.50 & 3.27 \\
\hline 2001 & 61.97 & 29.94 & 2.07 & 1.30 & 0.36 & 3.66 \\
\hline 2002 & 167.11 & 58.31 & 2.86 & - & - & - \\
\hline
\end{tabular}
recovery post-mitigation, for either abundance or population structure. These patterns of change are complex but consistent with the first successful steps of restoration of the Zostera noltii bed. After 1998, the controlled use of fertilisers, the opening of the upstream connection (residence time declined from 5-7 d to just $1 \mathrm{~d}$ ) between the 2 arms, the reduction of the number of fishermen digging for bait and the improved management of sluice openings led to an improvement of the environmental quality. All these actions promoted lower turbidity (from average particulate organic matter values of $0.02 \mathrm{mg} \mathrm{l}^{-1}$ before mitigation to $0.003 \mathrm{mg} \mathrm{l}^{-1}$ after mitigation; M. A. Pardal unpubl. data), a consequent increase in freshwater circulation that favoured nutrient dilution and decreased residence time, which improved the environment for 

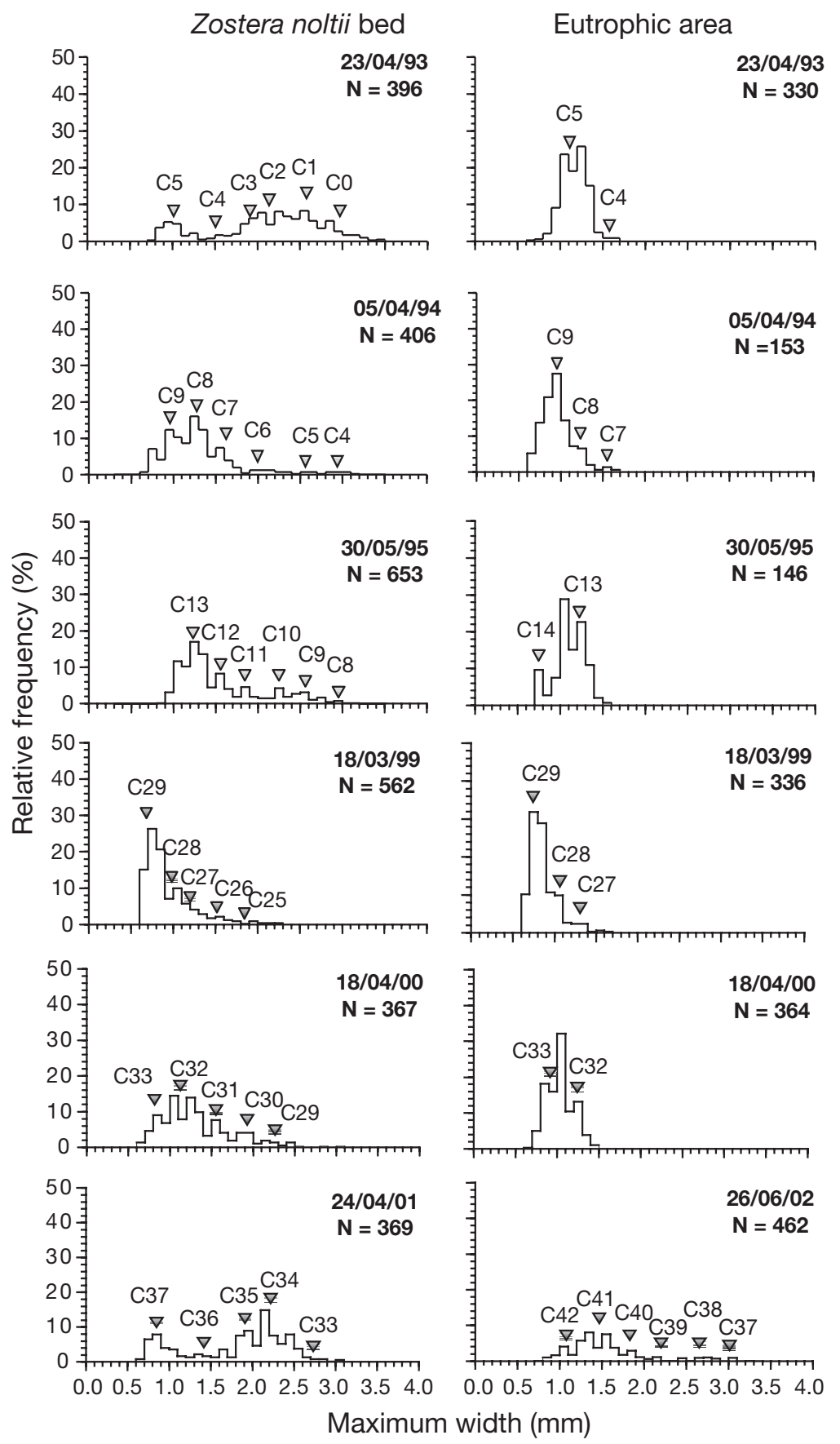

Fig. 6. Hydrobia ulvae. Size-frequency distribution in the Zostera noltii bed and in the eutrophic area. The cohorts (C) and the number of individuals are shown

the seagrass bed and reduced the risk of macroalgal blooms. We are confident, therefore, that the adverse environmental conditions caused by eutrophication are now abating.

Nevertheless, 2 questions remain. First, if eutrophication of the entire estuary has lessened, why has the biology of upstream eutrophic site not returned to its original state? Second, why has the recovery of the Hydrobia ulvae population following major flood events been slower than during the first period of the study? Although the recovery after floods was studied for only 2 events, we suggest that the answer to both questions involves the relative resilience of the seagrass bed and the eutrophic site, and the compounding effects of the 2 stressors, enrichment and flood events. We have argued elsewhere (Cardoso et al. 2004) that the intertidal flats of the Mondego estuary manifest 2 alternate states. The first is characterised by a vigorous seagrass bed, which because of its above- and below-ground structural complexity reduce critical erosion velocities and create a more benign nearbed environment for deposit feeders, as well as secondary habitat in the form of leaves and roots, and fine-particle sediment. The second state is one lacking rooted macrophytes with coarser sediment particles and an impoverished biota. The shift from seagrass to coarse sediment and vice versa is probably best described by hysteresis dynamics (Hobbs \& Norton 1996, Scheffer \& Carpenter 2003), where moving between the 2 alternate states requires a major perturbation (eutrophication or large-scale sediment stabilisation). Thus, even if eutrophication is completely reduced at the eutrophic site, recovery to the original state (covered with rooted macrophytes) probably will not take place in the absence of further restoration, such as extensive physical engineering of the bed (Cardoso et al. 2004).

The failure of Hydrobia ulvae to completely recover to a structured population, including all age classes at the eutrophic site, is consistent with this view of system stability. It is also interesting that the $H$. ulvae population at the eutrophic site seems less resilient than that in the seagrass bed, as indicated by the longer time to achieve the same values as previously reached following major flood events (Fig. 5). Also, the population in the seagrass site seems similarly less resilient to flood events following the earlier eutrophication period. If so, this would add weight to the concerns expressed by other workers, that multiple stressors (here, eutrophication and flood disturbance) operating concurrently or consecutively can act synergistically, to lower overall system stability (Kennish et al. in press). In this case, the eutrophication process, which leads to a decline of the seagrasses, will 

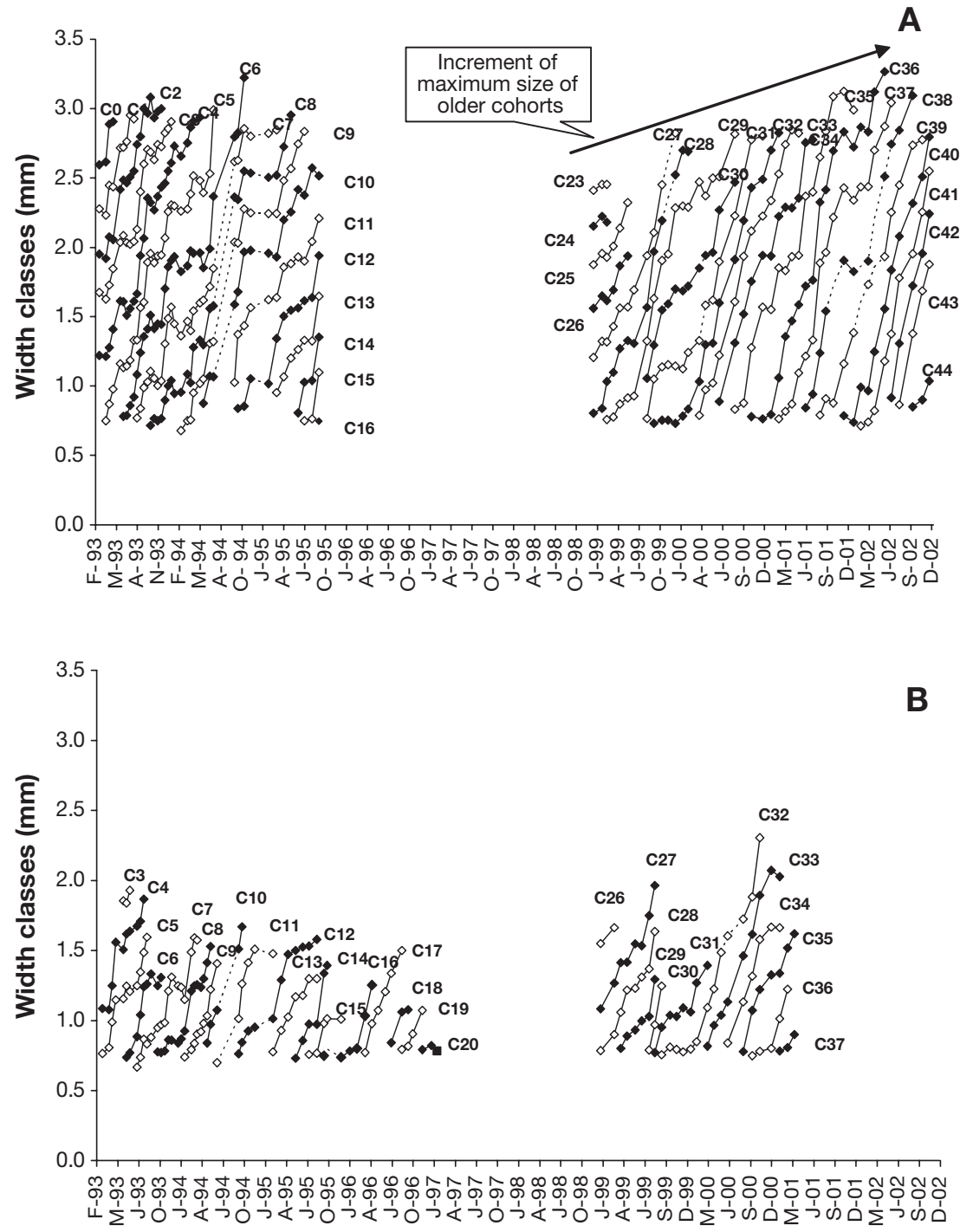

Fig. 7. Estimated growth of Hydrobia ulvae cohorts. (A) Zostera noltii bed; (B) eutrophic area

promote indirectly the disappearance of the majority of the reproductive adults. In the presence of a new stressor (e.g. floods), we find that the recovery of the population is much slower. This fact was more evident at the eutrophic site, in which no signs of population recovery were observed after the second flood event. This pattern reinforces the notion that both stressors acting synergistically can have an important role in the stability of the population. Such stability concepts need to be acknowledged in estuarine restoration programmes if the latter are to be successful.

One of the most dramatic differences in Hydrobia ulvae populations at the 2 sites is the virtual absence of adult (large size: $>1.5 \mathrm{~mm}$ ) cohorts at the eutrophic site. There are several possible explanations for this. First, growth rates at the eutrophic site may be lower than those in seagrass bed, such that the populations are es- sentially similar in their age structure. This seems unlikely on the basis of the results of the cohort analyses and field growth rates obtained (Fig. 7). Second, trematode parasites are known to induce gigantism in $H$. ulvae and alter population structures accordingly (Huxham et al. 1995). However, infection rates by trematodes in the Mondego estuary are very low $(<2 \%)$ and cannot account for the higher abundance of larger snails (Ferreira et al. unpubl. data). Third, size-selective removal of larger individuals by shorebird predation could be responsible for the observed between-site differences (Cabral et al. 1999). This seems the most likely explanation, given the obvious difference in refuges between the 2 sites. That predation is the mechanism responsible for the removal of larger snails explains the reduction in growth production, as well as the deficiency of large snails observed in the eutrophic area (characterised by bare sediments) and also in the Zostera noltii bed in 1999 (when the biomass of seagrass was lower). This mechanism associated with the reduction of food resources could have had a synergistic effect, leading to a more fragile and less resilient population in the post-mitigation period than at the beginning of the study.

In conclusion, it seems that the nutrient-mitigation strategy for the restoration of the estuary has been partially successful. There is evidence that the seagrass is recovering at the outermost site and that the Hydrobia ulvae population has the potential for recovery, although its resilience to further impacts (such as floods) may have been reduced. For the eutrophic site, there was some minor recovery of H. ulvae post-mitigation, but the resilience of the population at this site to a flood disturbance appears very low. Understanding the behaviour of biological populations following restoration initiatives requires acknowledgement that some changes may not be easily reversible and that the existence of multiple stressors may lower the resilience of populations.

Acknowledgements. This work was supported by FCT (Fundação para a Ciência e Tecnologia) through a $\mathrm{PhD}$ grant attributed to P.G.C. (SFRH/BD/5350/2001). The authors are indebted to all their colleagues who assisted in the field and lab work. 


\section{LITERATURE CITED}

Anderson A (1971) Intertidal activity, breeding and the floating habitat of Hydrobia ulvae in the Ythan estuary. J Mar Biol Assoc UK 51:423-437

Cabral JA, Pardal MA, Lopes RJ, Múrias T, Marques JC (1999) The impact of macroalgal blooms on the use of the intertidal area and feeding behaviour of waders (Charadrii) in the Mondego estuary (west Portugal). Acta Oecol 20(4):417-427

Cardoso PG, Lillebø AI, Pardal MA, Ferreira SM, Marques JC (2002) The effect of different primary producers on Hydrobia ulvae population dynamics: a case study in a temperate intertidal estuary. J Exp Mar Biol Ecol 277(2):173-195

Cardoso PG, Pardal MA, Lillebø AI, Ferreira SM, Marques JC, Raffaelli D (2004) Dynamic changes of seagrass assemblages under eutrophication and implications for recovery. J Exp Mar Biol Ecol 302/2:233-248

Clark JR (1996) Coastal zone management handbook. CRC Press, Boca Raton, FL

Dauvin JC (1986) Dynamique de la population d'Abra prismatica (Mollusque, Bivalve) de la baie de Morlaix (Manche Occidentale). Ann Inst Océanogr 62 (1):1-12

de Jonge VN, de Jong DJ, van Katwijk MM (2000) Policy plans and management measures to restore eelgrass (Zostera marina L.) in the Dutch Wadden Sea. Helgol Mar Res 54:151-158

Diaz RJ, Rosenberg R (1995) Marine benthic hypoxia: a review of its ecology effects and behavioural responses of marine macrofauna. Oceanogr Mar Biol Annu Rev 33:245-303

Dolbeth M, Pardal MA, Lillebø AI, Azeiteiro UM, Marques JC (2003) Short and long-term effects of eutrophication on the secondary production of an intertidal macrobenthic community. Mar Biol 143:1229-1238

Duarte CM (2000) Marine biodiversity and ecosystem services. J Exp Mar Biol Ecol 250:117-132

Duarte CM (2002) The future of seagrass meadows. Environ Conserv 29(2):192-206

Flindt MR, Kamp-Nielsen L, Marques JC, Pardal MA and 5 others (1997) Description of the three shallow estuaries: Mondego River (Portugal), Roskilde Fjord (Denmark) and the lagoon of Venice (Italy). Ecol Model 102:17-31

Franklin JF (1989) Importance and justification of long-term studies in ecology. In: Likens GE (ed) Long-term studies in ecology: approaches and alternatives. Springer-Verlag, New York, p 3-19

Hayden HS, Blomster J, Maggs CA, Silva PC, Stanhope MJ, Waalland JR (2003) Linnaeus was right all along: Ulva and Enteromorpha are not distinct genera. Eur J Phycol 38: 277-294

Hobbs RJ, Norton DA (1996) Towards a conceptual framework for restoration ecology. Restor Ecol 4:93-110

Huxham M, Raffaelli DG, Pike AW (1995) The effect of larval trematodes on the growth and burrowing behaviour of Hydrobia ulvae (gastropoda: prosobranchiata) in the Ythan estuary, north-east Scotland. J Exp Mar Biol Ecol 185:1-17

Jackson JBC, Kirby MX, Berger WH, Bjorndal KA and 15 others (2001) Historical overfishing and the recent collapse of coastal ecosystems. Science 293:629-638

Kendrick GA, Aylward MJ, Hegge ML, Cambridge K, Hillman K, Wyllie A, Lord DA (2002) Changes in seagrass coverage in Cockburn Sound, Western Australia between 1967 and 1999. Aquat Bot 73:75-87

Kennish MJ (2000) Anthropogenic impacts and the National Estuary Program. In: Estuary restoration and maintenance. The National Estuary Program. CRC Press, Boca Raton, FL Kennish M, Raffaelli D, Reise K, Livingston RJ (in press)
Environmental threats and environmental futures of estuaries. In: Polunin N (ed) Environmental future of aquatic ecosystems

Lillebø AI, Pardal MA, Marques JC (1999) Population structure, dynamics and production of Hydrobia ulvae (Pennant) (Mollusca: Prosobranchia) along an eutrophication gradient in the Mondego estuary (Portugal). Acta Oecol 20(4):289-304

Lopes RJ, Pardal MA, Marques JC (2000) Impact of macroalgal blooms and wader predation on intertidal macroinvertebrates: experimental evidence from the Mondego estuary (Portugal). J Exp Mar Biol Ecol 249:165-179

Marques JC, Maranhão P, Pardal MA (1993) Human impact assessment on the sub-tidal macrobenthic community structure in the Mondego estuary (Western Portugal). Estuar Coast Shelf Sci 37:403-419

Marques JC, Pardal MA, Nielsen SN, Jørgensen SE (1997) Analysis of the properties of exergy and biodiversity along an estuarine gradient of eutrophication. Ecol Model 102: $155-167$

Marques JC, Nielsen SN, Pardal MA, Jørgensen SE (2003) Impact of eutrophication and river management within a framework of ecosystem theories. Ecol Model 166:147-168

Martins I, Pardal MA, Lillebø AI, Flindt MR, Marques JC (2001) Hydrodynamics as a major factor controlling the occurrence of green macroalgal blooms in a eutrophic estuary: a case study on the influence of precipitation and river management. Estuar Coast Shelf Sci 52:165-177

Nogueira AJ (1992) ANAMOD - extracção dos componentes modais de distribuições de frequências de variáveis biométricas: provas de aptidão pedagógica e capacidade científica. University of Coimbra, Coimbra

Norkko A, Bonsdorff E (1996a) Population responses of coastal zoobenthos to stress induced by drifting algal mats. Mar Ecol Prog Ser 140:141-151

Norkko A, Bonsdorff E (1996b) Rapid zoobenthic community responses to accumulations of drifting algae. Mar Ecol Prog Ser 131:143-157

Pardal MA, Marques JC, Metelo I, Lillebø AI, Flindt MR (2000) Impact of eutrophication on the life cycle, population dynamics and production of Ampithoe valida (Amphipoda) along an estuarine spatial gradient (Mondego estuary, Portugal). Mar Ecol Prog Ser 196:207-219

Pardal MA, Cardoso PG, Sousa JP, Marques JC, Raffaelli D (2004) Assessing environmental quality: a novel approach. Mar Ecol Prog Ser 267:1-8

Peterson CH, Lipcius RN (2003) Conceptual progress towards predicting quantitative ecosystem benefits of ecological restorations. Mar Ecol Prog Ser 264:297-307

Planas M, Mora J (1987) Dinámica poblacional de Hydrobia ulvae (Pennant) en la ria de Pontevedra (NO España). Cah Biol Mar 28:447-464

Raffaelli DG, Raven JA, Poole LJ (1998) Ecological impact of green macroalgal blooms. Oceanogr Mar Biol 36:97-125

Reise K, Heere E, Sturm M (1989) Historical changes in the benthos of the Wadden Sea around the island of Sylt in the North Sea. Helgol Meeresunters 43:417-433

Scheffer M, Carpenter SR (2003) Catastrophic regime shifts in ecosystems: linking theory to observation. Trends Ecol Evol 18:548-656

Schramm W, Nienhuis PH (1996) Marine benthic vegetation: recent changes and the effects of eutrophication. Springer-Verlag, Berlin

Valiela I, McClelland J, Hauxwell J, Behr PJ, Hersh D, Foreman K (1997) Macroalgal blooms in shallow estuaries: controls and ecophysiological and ecosystem consequences. Limnol Oceanogr 42(5):1105-1118

Submitted: April 23, 2004; Accepted: December 14, 2004

Proofs received from author(s): March 9, 2005 